\title{
The Best of All Possible Worlds? MaAstricht AND THE UNITED KINGDOM
}

\author{
Ian Ward"
}

\section{INTRODUCTION}

In 1758, Voltaire wrote Candide, in which the young hero is whisked around the world in a series of increasingly ludicrous and tortuous adventures in the company of Pangloss, a "metaphysico-theologo-cosmolo-nigologist." Despite every possible misfortune, prompted by the blind optimism of a rationalism run riot, Candide remains convinced that all will be well. The saving grace is the fact that, despite every appearance to the contrary, he does live in "the best of all possible worlds."

As an analogy with the present condition of European Community politics, Candide's fate is an appropriate one. Post-Maastricht Europe too, we are assured, will be the best of all possible worlds. Despite every appearance to the contrary-the repeated difficulties that ratification of the Treaty has experienced in certain member states, the volubility of anti-Maastricht criticism, and the virtually uniform condemnation of the Treaty provisions by political and legal commentators-the immanent "righteousness" of an integrated European order has preserved the idealised inevitability of Maastricht. Maastricht has become so much more than just a constitutional or political issue. It has become

* Ian Ward is currently a Senior Lecturer in Law at the University of Sussex, UK. He is a former Lecturer in Law at the University of Durham, and has held visiting positions at the Comenius University, the Catholic University of Portugal, the University of Iowa and the University of Oslo. His current research interests lie in the areas of European law, comparative law and jurisprudence. His academic credentials are as follows: B.A. in Law and History, 1986, University of Keele; Ph.D., 1989, University of Cambridge; and LL.M., 1990, University of Toronto.

** I should like to thank a number of people who assisted me at various stages of this article. I should first of all like to thank members of the Faculty of Comparative Law at Comenius University in Bratislava, and the Faculty of Law at the Catholic University of Portugal in Lisbon, to whom I gave versions of this article. I should also like to thank Professors David O'Keeffe and Neil MacCormick, Clare McGlynn, Pat Twomey and Colin Warbrick, who at one time or another all commented upon various of the issues encompassed within the article.

1. Voltaire, The Critique of Pure Reason, Candide (Harmondsworth, 1947). Like so many eighteenth century Europeans, he questioned the blind faith of Enlightenment rationalism. Twenty-one years later, Immanuel Kant published the first of his three Critiquesfor precisely the same reason. Kant seriously doubted whether pure logic would, or even could, lead mankind to its unavoidable destiny, or to use Hegel's concept, the "overcoming" of itself. Where Kant produced a substantive metaphysics which would gear the following two centuries of critical philosophy, Voltaire penned one of the most enduring and biting satires in modern literature. 
an image. As The Times commented, "The shimmering vision of a new European order enshrined in the Maastricht treaty is a mirage, forever just out of reach."2 Rather like Coleridge's Xanadu, everybody is convinced that Maastricht represents something that is incontrovertibly desirable, but somehow the vision remains forever just out of range of reality. On exactly the same day, another influential UK newspaper, The Guardian, suggested that the Danish people, on the eve of their second referendum for ratification of the Treaty, were being "asked to vote for Maastricht because, like Everest, it is there . ... The question, stripped of all detail and legalities, has become one of simple, emotional response." ${ }^{\prime 3}$

The hard political realities and repercussions of the Maastricht Treaty have been far greater than was ever originally envisaged, and, as will be suggested shortly, have shaken the present British government to its foundations. The potential constitutional and legal repercussions are no less considerable. Maastricht presents a new and fundamentally ill-determined constitutional order. Rarely have academic commentators been so united in condemning a legal document. The Maastricht Treaty is, in simple terms, a desperately inept and thoroughly confusing document.

The purpose of this article is to investigate the Treaty as a constitutional and legal document and to suggest why constitutional and legal commentators have been so scathing in their criticism. At the same time, a collateral purpose is to present a paradox. Whilst so many anti-Maastricht campaigners in the UK have, at times almost hysterically, railed against the explicit and implicit threats to constitutional sovereignty and the democratic failings of the Treaty, it may well be that the Treaty itself represents the most damaging development in the process of European integration since the very inception of the European Community. In other words, the one thing that might prevent further integration is the very document that was designed to facilitate it.

The first part of the article investigates the politics of Maastricht from the standpoint of the UK. One purpose is to discuss the extent to which the Maastricht issue has impacted the UK constitution and the domestic political scene. A second collateral purpose is to introduce the specific concessions that the UK secured at Maastricht and to suggest their possible repercussions, both in the UK and in the Community as a whole. The second part of the article then considers the particular legal effect of the Treaty, or more accurately, its legal failings. It suggests that, rather than resolving the increasing difficulties which lawyers experience in trying to operate within the dual system of EC and domestic law and the inevitable anomalies which result, the Treaty only

2. Janet Bush, Recession is Greater Threat to Maastricht than the Danish Vote, THE TIMES (London), May 17, 1993, at 42.

3. The Guardian, May 17, 1993, at 19. 
serves to exacerbate these anomalies and to shroud the Community legal order in even greater confusion.

\section{THE POLITICS OF MAASTRICHT}

\section{i. Discord in Zion}

During the 1650's, another decade when politicians clung even more tenaciously to a succession of unquestioned ideals callibrated by a semiotic of blind optimism, Oliver Cromwell would reassure the increasingly bewildered and bemused members of the various Parliaments that there is "always discord in Zion." There has been much discord in Westminster in recent months for two reasons: first, the concern over whether there should be a European Union; and second, and perhaps most importantly, at least in the context of this essay, whether the Maastricht Treaty is the way to go about it.

The power of the European ideal was revealed strikingly in 1990, when it effectively destroyed the Thatcher premiership. Regardless of questions of political ideology, Margaret Thatcher's reign as Prime Minister was, in the context of British politics, no ordinary premiership. Thatcher had remained virtually unchallenged at the head of government for eleven years. ${ }^{4}$ The issue which finally lost Party support, and most importantly Cabinet support, was Europe. Until Thatcher questioned, not the existence of Xanadu, but the actual desirability of getting there anyway, she had enjoyed comfortably the longest and probably the most secure premiership in recent history. ${ }^{5}$ One mistake (at least one that mattered) destroyed Thatcher with a speed and force which left political commentators reeling. ${ }^{6}$ But no one was allowed to stand in the way of the "best of all possible worlds." In fact, the resignation of Sir Geoffrey Howe, the only Minister to have served throughout all three administrations since 1979, precipitated Thatcher's spectacular fall from grace.

4. For a commentary on her control of Cabinet government, see Peter Clarke, Margaret Thatcher's Leadership in Hislorical Perspective, 45 PARLIAMENTARY AFF. 12 (1992).

5. It has been suggested that little more than a year earlier, Thatcherism had "achieved its apotheosis." The Thatcher administrations had been characterized by the hiring and firing of Ministers with almost breathtaking alacrity. It seemed that there was nothing that Thatcher could do that would upset anyone enough to protest. Even the recent constructive dismissal of Chancellor Lawson, over the desirability of entering a European monetary system, seemed to pass with little more than a polite murmur of interest. See id. at 11, 15 .

6. See R. K. Alderman \& Neil Carter, A Very Tory Coup: The Ousting of Mrs. Thatcher, 44 PARLIAMENTARY AFF. 125 (1991) (referring to her "spectacularly abrupt" departure "as though an immovable institution had been overthrown"). See also Clarke, supra note 4, at 16 (describing Thatcher's fall from power as "staggeringly sudden"). 
Howe's resignation speech in the House of Commons, which, with a stunning understatement, he suggested was due to a "growing difference" of opinion over Europe, provided, as one commentary suggests, "both the issue and the trigger" for the cataclysmic events of the following weeks.

Not only did Howe's resignation precipitate Thatcher's demise, it also reawakened fundamental divisions within the Conservative Party over the role of the UK in Europe. His resignation letter suggested that the divisions within government, even at Cabinet level, had been barely papered over for the previous five years. The resignations of senior Ministers Heseltine, Lawson and Ridley, he added, had all been forced by the European issue. ${ }^{8}$ When Heseltine returned to challenge Thatcher for the leadership of the Party and the Premiership, he did so by highlighting the European issue. Although Thatcher won the first ballot by a bare four votes, it was a wholly Pyrrhic victory. Heseltine failed to secure the leadership of the Party and the country, but he returned to a new Cabinet of committed pro-Europeans, which was led by the most committed of all, Prime Minister Major and Foreign Secretary Hurd.

The inheritance, however, has proved to be something of a poisoned chalice. The first three years of John Major's premiership have been dominated by the Maastricht issue, in a way in which it is hard to find a comparison. Since the 1992 election, which reduced the Conservative Party majority in the House of Commons to just nineteen, Major has been faced with an intransigent minority of between twenty and thirty Euro-sceptics who have displayed and articulated a constant willingness to destroy the Government before accepting the Maastricht Treaty.

The piloting of the Maastricht bill through Parliament more than once threatened to sink the Major boat on precisely the same "submerged rock of Europe" that sank Thatcher. ${ }^{10}$ The first overt sign of difficulties was the rebellion of twenty-six Tory MPs in the "Paving Motion" in November 1992. The "Motion" was a not-to-be-repeated bluff, called by Major on the European principle, in an effort to bully the Party into line. Having repeatedly made clear that a defeat in the motion would lead to his and possibly even the government's resignation, Major, with a threadbare Parliamentary majority of nineteen MPs, won the vote by an even more threadbare majority of just three, by $319-316$. The previous days, during which it had looked at times as though defeat was inevitable, had witnessed "whipping" measures of almost

7. See Alderman \& Carter, supra note 6, at 128.

8. See id. at 128-29.

9. See id. at 128-39 (commentary on the party elections).

10. See Clarke, supra note 4 , at 16. 
unparalleled ferocity." Such was the strength of rebel feeling, and the incontrovertibility of their argument, that Major was forced, paradoxically, to take the stand that the vote was purely and simply a confidence vote, and moreover, that given the presence of the principle of subsidiarity in the Maastricht Treaty, the actual bill itself was of "very little significance." 12 It was a curious volte-face.

The vexed issue of subsidiarity and the UK approach to it will be considered in the next section of this article. The "Paving Motion," far from being the end of the issue, was, in fact, only the beginning. The continued travails of the Major administration in securing the passage of the bill, and the repeated volte-face suggesting that the bill really does not matter anyway, is considered in section iii.

\section{ii. The Politics of Compromise: Subsidiarity and the F-Word}

On assuming the leadership of the Party and the country in 1990, Major was well aware that carrying the Conservative Party along the road to ratification of the Treaty represented a considerable hurdle. The demise of his predecessor was a sobering illustration of what might befall a Prime Minister who failed to play the European card with dexterity. One of the more interesting characteristics of Major's Premiership is his habit of "pulling rabbits out of hats." ${ }^{13}$ Thus, it was at Maastricht, when everyone prophesied an inevitable doom, that Major was able to stand, apparently alone (although, in fact, he

11. The UK's humiliating withdrawal from the European Exchange Rate Mechanism, after a failed attempt to bolster the pound sterling had swallowed a quarter of the country's gold reserves, provided the Euro-sceptics with precisely the opportunity they sought. Rather than having to campaign solely on the principled issues of sovereignty and federalism, which alone were able to spawn considerable Party discontent, the Sceptics were also able to point to a stark and recent example of precisely how the European ideal as enshrined in the Maastricht Treaty simply did not work. For a commentary on the nature of Tory Euro-scepticism and its policy of waiting for the inevitable practical deficiencies in working through the common economic policies enshrined in Maastricht, see S. Bulpitt, ConservativeLeadersand the EuroRatchet: Five Doses of Scepticism, 63 POL. Q. 258 (1992). The subsequent collapse of the entire EMS system has, of course, born out the validity of this approach. For an account of the "Paving Motion," see David Baker et al., Whips or Scorpions? The Maastricht Vote and the Conservative Party, 46 PARLIAMENTARY AFF. 151 (1993).

12. See Baker et al., supra note 11 , at 156.

13. As one commentator has observed, Major has developed the habit of "giving the impression of drowning . . . in the tumultuous seas of publicity-mongering politics; and then emerging, when people thought he had drowned, bringing the results he had promised to obtain." See Editorial Note, The Deeper Meanings of Mr. Major's Second Victory, 28 GoV'T. \& OPPOSITION 4 (1993). 
enjoyed the important, but considerably less provocative, support of Portugal and Denmark), and to demand the removal of the word "federalism" from the Treaty and the inclusion of the principle of subsidiarity, and to secure the UK "opt-out" from the Social Chapter. ${ }^{14}$ The effect of the Social Chapter "opt-out," in particular its potential ramifications in domestic politics, is considered in the next section.

The other two concessions that Major wrung from the Maastricht summit have far wider implications. The removal of federalism represented the removal of the central pillar of the originally intended constitutional redesign that the Treaty was supposed to present and facilitate. The Final Draft of the Treaty on Political Union, as drafted by the Dutch Presidency, modified at the Maastricht summit, and produced in December 1991, stated in Article A of the Common Provisions that the "Treaty marks a new stage in the process leading gradually to a Union with a federal goal." 15

For many pro-Europeans, and for the vast majority, it is fair to say, a fully federal Europe has always been the Holy Grail. It was certainly the original and often asserted ambition of the founding father of the Community, Jean Monnet. At Maastricht, all member states, save for the UK, Portugal and Denmark, subscribed to the ideal and advocated its inclusion in the Treaty. However, the Final Draft was accurate in every detail except one-it was not final. When the final version of the Treaty emerged in the following February, Article A, though still describing a "Union," had been changed to read that "[t]his Treaty marks a new stage in the process of creating an ever closer union among the peoples of Europe in which decisions are taken as closely as possible to the people." ${ }^{16}$

The change was significant in two respects. First, and most obviously, it had removed the F-word: "federalism." Only too aware of the difficulties that he would face in trying to present a Treaty acceptable to his country, and much more importantly to his Party, Prime Minister Major furthered his vital hopes of steering domestic legislation through Parliament by removing federalism. Perhaps only a symbol, it was a vital one nonetheless. In a vein deliberately reminiscent of his predecessor, Major at least appeared to champion the interest of the British over that of the Europeans. ${ }^{17}$

14. And contingently from the European Monetary System. For a general introduction to these "opt-outs," see Charles Bidwell, MAASTRICHT AND THE UK (PACE 1993).

15. Europe Documents No. 1750/1751, Final Draft of the Treaty of Political Union Prepared by the Dutch Presidency, at 3.

16. For the text of the Treaty and a commentary on its provision, see Bidwell, supra note 14.

17. It has been suggested that Thatcher's approach to European politics was "to rampage from summit to summit as a sort of fishwife Britannia demanding her money back." See Clarke, supra note 4, at 15 . 
The second change is important in that it reflected the elevation of the principle of subsidiarity into one of the central Provisions of the Act. Subsidiarity was thus the second great "victory" for Major on his return from Maastricht. At least that is true of Major's interpretation of subsidiarity. If, on the other hand, the German or French, or indeed everyone else's interpretation of subsidiarity is correct, then it is, on the contrary, potentially Major's most serious mistake. Subsidiarity is at least as much, if not more, of a political than a legal concept. ${ }^{18}$ The Oxford English Dictionary defines subsidiarity as "the principle that a central authority should have a subsidiary function, performing only those tasks which cannot be performed effectively at a more immediate or local level." So far so good. Unfortunately, interpretation, and thus potentially implementation, of subsidiarity has spawned a myriad of potential meanings which has belied the apparent simplicity of its original definition.

The principle of subsidiarity had been originally submitted by the European Commission for inclusion in the Tindemans Report on European Union in June 1975. It was not, however, adopted. The principle returned in the highly integrationist 1984 "Draft Treaty Establishing the European Union," drafted by the European Parliament. Although it was not formally adopted in the 1986 Single European Act, its inclusion in Article 130R(4) in the area of environmental affairs, represented the arrival of subsidiarity as a respectable European policy ideal; at this stage, it was cherished by integrationists as one of the pillars of a fully federated European order.

Amongst the strongest advocates of subsidiarity were the Germans, whose own federal constitution included subsidiarity, and from whom the principle was essentially grafted. For the Germans, subsidiarity is federalism. The then Dutch President of the Council, Ruud Lubbers, declared, "I respect subsidiarity. As you know, for the Germans, the word for this is federalism."19

Integrationists were thus, as one commentator has observed, somewhat "surprised," if not perturbed, by the sudden enthusiasm for subsidiarity articulated by an increasingly skeptical UK government. The more firmly the Thatcher and Major administrations dismissed the idea of federalism, the more keenly it seemed to approve the principle of subsidiarity. Whereas the German-Dutch-French interpretation of subsidiarity maintains that the Community should undertake actions which can be better achieved or attained at a supranational level, the British interpretation maintains that subsidiarity

18. The potential legal repercussions are discussed later in Part II, section ii of this article.

19. The application of subsidiarity in the Treaty document even received the enthusiastic approval of U.S. Secretary of State James Baker, who identified subsidiarity as "that which we in the United States call federalism." See A. Teasdale, Subsidiarity in Post-Maastricht Europe, 64 THE POL. Q. 189 (1993). 
means Community action can only be undertaken when it is necessary or essential for the securing of the objectives in question.

Both sides prepared their own drafting of the principle for inclusion in the Treaty. The result was Article $3 b$, a classic piece of Euro-fudge which was hoped to be "just about acceptable to everyone." However, as one commentator has observed, it "satisfied nobody completely." ${ }^{20}$ Article $3 \mathrm{~b}$ reads:

In areas which do not fall within its exclusive competence, the Community shall take action, in accordance with the principle of subsidiarity, only if and in so far as the objectives of the proposed action cannot be sufficiently achieved by the member states and can therefore, by reason of the scale or effects of the proposed action, be better achieved by the Community. ${ }^{21}$

The inclusion of the two interpretations produces an immanent and unavoidable confusion in the text. The potential legal repercussions are considered subsequently, where it is suggested that the interpretation will ultimately have to be decided by the European Court of Justice, even though prima facie the issue is potentially non-justiciable. It cannot be said with any particular confidence that the Court will rule in Major's favour. Subsidiarity remains one of the pillars of the Treaty and the envisaged "new" European order. It is, thus, an enduring pity that the requirements of political expediency necessitated a deliberately obtuse definition of the term in the Treaty document. In the words of one political commentator: "The absence of clear guidelines ... tends to suggest that the reason why the definition of subsidiarity in the Maastricht Treaty is so vague is precisely because there can be little agreement at a political level on the substance of the concept in the European Community today." ${ }^{22}$ The failure at Maastricht to present subsidiarity as a definitive political and legal concept, and more than just an ephemeral ideal, is symptomatic of a Treaty that singularly fails in its greatest original ambition: to present a comprehensive and workable new political and legal order.

\section{iii. The Politics of Sovereignty: The Amendment Debate}

Prime Minister Major's Maastricht concessions have returned to haunt him. The repercussions of subsidiarity on the political and the legal order in Europe may well prove to have a long-term debilitating effect, and are

20. Id. at 191 .

21. Maastricht Treaty art. 3b (emphasis added).

22. Teasdale, supra note 19 , at 191. 
considered shortly. The more immediate ghost, and one which took virtually the entire parliamentary year to exorcise, was the Social Chapter Protocol or "opt-out." In fact, the UK also secured an opt-out which permits it to reconsider at a later date whether or not it wishes to join a common currency. It was, however, Major's third great "victory," the Social Chapter Protocol, which stole the limelight and almost proved to be his undoing.

The Social Chapter, regardless of its ideological content, as a piece of legislation, is uniformly denounced, even by its supporters, as immanently at odds with the principle constitutional pillars of the Treaty. In the supposedly non-federal Union, the most glaring problem is the contradiction between the de-centralising status, or at least intention, of subsidiarity and the irreducibly centralising nature of the Social Chapter. ${ }^{23}$ From a particular UK perspective, the articles of the Social Charter in large part reverse much of the employment legislation which had been piloted through Parliament by the Conservative governments during the 1980 's. It was this that drove Major's insistence that the UK should opt out of the Social Charter. Inspired by such success at protesting so loud and so long about the desirability of a new European order, and then opting out of one of the most important parts, other countries immediately followed suit, opting out of whichever bits seemed least desirable. ${ }^{24}$ The effect of the Protocol in law is considered below.

The more immediate political effect in the UK has been considerable. Whilst the Protocol preserved existing employment legislation, and could be championed by John Major as another example of "batting for Britain," it provided a critical weapon for his opponents. Not the least of the peculiarities in the passage of the Maastricht legislation has been the joint enthusiasm of all major political parties for it. Back in the nineteenth century, the revered constitutionalist Walter Bagehot highlighted the "duty" of the Opposition to oppose. ${ }^{25}$ Yet, the only issue upon which the Opposition has shown itself willing to challenge the government is the Social Chapter Protocol.

23. For a scathing criticism of the ideology and the practicalities of the Social Charter, see Christopher Lingle, The EC Social Charter, Social Democracyand the Post-1992 Europe, 14 W. EUR. POL. 129 (1992).

24. Including the Danes, who wished to maintain existing legislation on the acquisition of second homes, and the Irish, who wished to maintain the constitutionality of their abortion clause, Article 40.3.3 of the Irish Constitution. But none were as central to the original ambitions of the Treaty as the Social Charter.

25. Repeatedly over the past 12 months, the Opposition has steadfastly refused to defeat the government, and at least potentially, bring it down. Such is the transcendental power of the European ideal. See generally Colin Turpin, BRTISH GOVERNMENT AND THE CONSTITUTION: TEXT, CASES AND MATERIALS 445 (2d. ed. 1990) (for the role of the Opposition in the UK Constitution). 
The varied and frequently inconsistent attempts to do so have centred around the tabling of various amendments to the European Amendment Bill which would require inclusion of the Chapter in domestic law. The tabling of successive amendments (numbers 27 and 74 prior to passage of the bill, and finally amendment 2 prior to ratification, all of which were designed to replace the former and to reduce the possibilities of the government evading inclusion of the Chapter) saw the passage of the bill descend into ever deeper and more labyrinthine procedural technicalities.

Amid various accusations of skullduggery, the government managed to negotiate the potential disasters, not least by bluffing the Commons, through the Attorney-General, that none of the amendments were anyway workable and were thus unenforceable at law. ${ }^{26}$ The government's success in having the Social Chapter opt-out discussed only after Royal Assent effectively secured its eventual passage. In response, the Opposition rather truculently refused their last opportunity to defeat the government by abstaining from the vote on Third Reading. The Opposition neither approved nor disapproved the bill, which duly received the Royal Assent on July 20, 1993.

However, the doubts surrounding the legal status of the second Amendment remained. Though the European Amendment Bill had already passed into law, Amendment 2 to section 7 of the Bill called for inclusion of the Social Chapter prior to ratification of the Treaty. Again, there was much debate with regard to the alleged legal authenticity of such an amendment, and again the Government, through the Attomey-General, was adamant that such an amendment could not effect the ratification which pertained to an international treaty and was a matter of executive action. ${ }^{27}$ However, regardless of these political niceties, the amendment vote that, if passed, threatened to launch a series of time-consuming legal actions in both the domestic and European courts, presented a major political hurdle. On July 22, 1993, amidst scenes which one national newspaper described as "mass hysteria," the Government scrambled through Amendment 2, tabled by the Labour opposition, which sought to include the Social Protocol in legislation prior to ratification. ${ }^{28}$

26. The Deputy Speaker's resultant refusal to accept the tabling of either amendments 27 or 74 at Committee Stage even resulted in a vote of "No Confidence" in his position. The motion was rejected by $450-81$, but the fact that there had not been such a motion for 21 years graphically illustrated the strength of feeling of many MPs, who felt that the last chances of defeating both the government and the bill were vanishing in a mire of procedural technicalities.

27. See Baker et al., supra note 11 , at 163.

28. The vote tied at 317-317, and only the convention of the Speaker's casting vote in support of the Government secured its passage. There were 15 Conservative rebels voting with the opposition and eight abstentions. In a second supplementary division, on a motion tabled by the Government confirming acceptance of the Treaty as it then stood, however, the Government suffered a humiliating defeat by $316-324$, with all 23 rebels voting with the 
As the confidence of the government has oscillated, so too has the official approach to the Maastricht Treaty. At certain moments, it secures the British "role in the centre of Europe." On other occasions, when defeat has seemed likely, particularly over a Social Chapter, the government, rather like the little boy who refuses to play and threatens to take his ball home if he doesn't win, attitude has been that the bill does not matter anyway because the Treaty can be ratified through executive action. These exclamations, of course, do little except incense opponents and, more interestingly, open up again the vexed and ever-returning problem of sovereignty.

The fact that international treaties can be ratified by executive action is not doubted. However, the legal status of such treaties in domestic courts of law is certainly doubted. Furthermore, the suggested irrelevance of the bill, apart from rather obviously begging the question of why the government is so desperate to secure its passage, casts very serious doubts on the orthodox accommodation of European law and UK sovereignty. This orthodoxy was immediately tested in the action taken by Lord Rees-Mogg, questioning the power of Parliament to ignore its earlier wishes. Before discussing this action, it is necessary to briefly consider what is said in the supposed orthodoxy.

Unaccustomed to any degree of political or legal federation, the UK, on accession to the Community in 1972 and thus to the Community legal order, was faced with a particular dilemma with regard to the issue of sovereignty. The orthodox theory, which developed following the accession

opposition. The repeated assertion that the Government would ignore the wishes of the House anyway and ratify through executive action proved to be a critical mistake and served only to harden rebel opposition. The Amendment Act required the passing of such a supplementary motion. Throughout the day, much speculation hung on the voting intentions of nine Ulster Unionist MPs who, after much cajoling and various unconfirmed promises of political reforms in the Province, agreed to support the Government. They also did so on the $23 \mathrm{rd}$. It was subsequently discovered that, in the general "hysteria" of the Chamber, the tellers had counted incorrectly on the first Amendment vote, and the Government had, in fact, won anyway at 318-317 and did not require the Speaker's casting vote. See Anthony Bivens, The Maastricht Debate: Major Faces the Ultimate Challenge, THE INDEPENDENT, July 23, 1993. Prime Minister Major's response, the only conventional response following such a defeat, was to immediately table a confidence motion for the following day, which was deliberately drafted to demand acceptance of the Treaty legislation at the same time as expressing confidence in the government. The scarcely veiled threat was that continued opposition to the legislation would result in the collapse of the government. As one newspaper put it, the rebels' "bluff was called," and the government secured its motion of confidence by 339-299, having earlier defeated the retabling of Labour's opposition Amendment by 339-301. The quotation used repeatedly by newspapers on the morning of the 24th was Lord Wellington's statement that the events of the 22nd and 23rd had been "a damned close thing." Given the Government standing in the polls, it was rather more prosaically suggested that "Turkeys rarely vote for Christmas." See THE GuARDIAN, July 24, 1993, at 1-3, 21. 
to the Community in 1972, was of a "dual constitution" with two sets of laws-domestic and European-subject to the principle of Parliamentary sovereignty.

The practicalities of this accommodation might have been questionable, and no one really imagined the possible scenario of exercising this sovereignty and leaving the Community, but in theory all was relatively neat and tidy. The thesis was famously articulated in McCarthy's $v$. Smith, where Lord Denning stressed that domestic courts would interpret domestic legislation in accordance with the principles and intent of European law. Where there was any conflict, the court would resolve it in favour of European law, which was, as a matter of principle, prior. This priority was enshrined in domestic law, by the European Communities Act, Section 2. It was thus prioritised by Parliament, and only Parliament's contrary intention, explicitly stated by statute, could alter this priority. ${ }^{29}$

There was much praise for Denning's accommodation or, as one commentator termed it, "Lord Denning's dexterous revolution." ${ }^{30}$ There was also much criticism. ${ }^{31}$ The "dual" nature of the UK Constitution has remained the orthodoxy in domestic courts. In Factortame 1, Lord Bridge made a very sharp distinction between EC law and domestic law, and described them as wholly separate sources of law, although both were subject to the sovereignty of Parliament. ${ }^{32}$ The thesis has been recently approved by Lord Oliver in Litster and Lord Justice Glidewell in Webb. ${ }^{33}$

But what if Parliament no longer prioritises European law? Or indeed, what if Parliament had decided to prioritise the Social Chapter and enshrine it in statute? According to the Attorney-General, the government could ignore Parliament and ratify the Treaty as an executive action; however, this makes Denning's view of sovereignty difficult to accept. Lord Rees-Mogg's action was a direct challenge to Denning's accommodation. First, it suggested that Parliament in 1993 ignored the prior intention of Parliament in 1978, which required that any subsequent legislation altering section 6 of the 1978 European Parliamentary Elections Act should express the explicit contrary. intention

29. [1979] 1 All E.R. 325; 1981 Q.B. 180.

30. See T. Allen, Parliamentary Sovereignty: Lord Denning's Dexterous Revolution, 3 OXXFORD J. LEGAL STUD. 22 (1983). See also T. Allen, The Limits of Parliamentary Sovereignty, PUB. L. 617 (1983).

31. Allen was somewhat ambiguous in his observations, conceding that the accommodation was "attractive," but suspecting that Parliament had fettered its discretion by seeming to require explicit repudiation of the 1972 Act. Allen, supra note 31, at 25-26. For a less compromising critique, see G. Anav, Parliamentary Sovereignty: An Anachronism?, 27 ColUM. J. TRANSNAT'L L. 647 (1989).

32. Regina v. Transport Secretary, Ex p. Factortame Ltd., [1989] 2 W.L.R. 1021-22.

33. Litster v. Forth Dry Dock and Engineering Co. Ltd., [1990] 1 App. Cas. 546; Webb v. EMO Cargo Ltd., [1992] 2 All E.R. 43. 
of Parliament. Second, in similar vein, it implied that the ratification of the Social Chapter Protocol was itself unlawful in European law as established by the Treaty of Rome, and was thus unlawful in UK domestic law as counter to Parliament's wishes in 1972, which had established European law as fundamental domestic law. Regardless of the constitutional niceties created by Lord Denning, the Divisional Court would not exercise what it deemed to be a power of constitutional review and duly dismissed the application. ${ }^{34}$ But in academic circles the doubts remain.

These doubts with regard to Lord Denning's accommodation, which were expressed long before the Rees-Mogg action, have encouraged alternative variations on the theory of sovereignty. Most recently, Professor MacCormick has suggested that the accommodation of the traditional Diceyan view of unitary sovereignty was fine as a transitional model for its "times" (i.e., the 1970's), but is no longer valid. ${ }^{35}$ MacCormick's view of a plural sovereignty in the UK, as developed from a Hartian as opposed to purely Austinian-Diceyan view of sovereignty, is the only existing theory that can adequately accommodate the inclusion of a Maastricht Treaty ratified by government, with or without Parliamentary support. ${ }^{36}$

Essentially the same thesis, in a much less developed form, has been presented by Professor Koopmans as a means for redefining the "federalism debate. ${ }^{137}$ The fact that the Treaty was enshrined in domestic law does not detract from the fact that the government, on advice from the Attorney-General, determined the Treaty could be ratified. Thus, and most importantly, it could effectively become part of domestic law, regardless of whether it was backed by domestic legislation, due to the principle of supremacy of European law. MacCormick similarly notes that the increasing strength of the principle of supremacy of European law, subject to no superior sovereignty, can only establish an independent sovereignty of equal status to a domestic one. ${ }^{38}$ If we are, as MacCormick suggests, "beyond the sovereign state," then it does

34. See Regina v. Secretary of State for Foreign \& Commonwealth Affairs, ex parte Rees-Mogg, The Guardian, July 30, 1993, at 4. The court al so dismissed a third challenge to the Amendment Bill, which suggested that the transference of royal prerogative powers to EC institutions would be unconstitutional.

35. See N. MacCormick, Beyond the Sovereign State, 56 MOD. L. REV. 1 (1993).

36. See id. at 16 (suggesting that it seems obvious that no state in Western Europe is any longer a sovereign state. None is in a position such that all the power exercised internally in it, whether politically or legally, derives from purely internal sources. Equally, of course, it is not true that all the power which is exercised either politically or normatively is exercised by, or through, or on the grant of, one or more organs of the European Community.).

37. See T. Koopmans, Federalism: The Wrong Debate, 29 COMMON MKT. L. REV. 1047 (1992).

38. See MacCormick, supra note 35 , at 4. 
rather beg the question of why the UK insisted on the removal of federalism from the Treaty and why subsidiarity is supposed to assist domestic sovereignty. One way or the other, the attitude of the UK government towards the ratification of the Treaty, with or without Parliamentary legislation, does demand a very long, hard look at the position of the UK within a "new" constitutional order that has been so substantially modified to accommodate the continuing orthodoxy of unitary Parliamentary sovereignty.

\section{THE JURISPRUdENCE OF MAASTRICHT}

\section{i. The Lawyer's Dilemma}

Whilst the constitutional repercussions of the amendment issue, and on a wider scale, the status of UK sovereignty within the Community, have been sources of much fascination to constitutionalists, confusion has been no less evident at the cutting edge of the legal system in the domestic courts. Many principles of European Community law, from a largely alien civil law tradition, have proved to be both confusing, and at times, wholly unsuitable to judges, who have, on a number of occasions, quite openly failed to implement European law. ${ }^{39}$ The full effectiveness of European law and directives is another of the hallowed principles of European law, and has a direct impact on the vexed issue of division of competences, generated by the continuing advocacy of the theory of constitutional "duality."

The failure of the UK, and indeed other member states, to fully implement directives has been a cause of anxiety to both academic observers and to the judges in the European Court. The failures, in large part, stem from an unsureness about where the competence of European law ends and that of domestic law begins. Maastricht represented an opportunity to reinforce and to regularise the application and exercise of European Law. Its failure to do so has led to widespread condemnation among academic observers. ${ }^{40}$

The principle of effectiveness, as enshrined in Article 5 of the EC Treaty, requires that:

Member States shall take all appropriate measures, whether general or particular, to ensure fulfillment of the obligations arising out of this Treaty or resulting from action taken by the institutions of the Community. They shall facilitate the achievement of the Commu-

39. One commonly cited example is the principle of proportionality. For a discussion of this principle and its somewhat patchy application in UK courts, see S. Boyron, Proportionality in English AdministrativeLaw: A FaultyTranslation?12 OXFORD J. LEGAL STUD. 237 (1992).

40. These criticisms are considered below, in the final part of the essay. 
nity's task. They shall abstain from any measure which could jeopardise the attainment of the objectives of this Treaty.

Suitably vague, the Article can be made to mean just about anything that one wishes, and has been. The principle of effectiveness thus has been solely developed by the jurisprudence of the European Court of Justice, which has determined, to the extent that they are at all defined, the divisions of competence. ${ }^{41}$ The three most important recent decisions which have illustrated the increased determination of the Court to ensure full effectiveness are Von Colson, Marleasing and Francovich. In Von Colson, the European Court held that Article 5 imposed an obligation on domestic courts to interpret implementing legislation in light of the wording and purpose of the directive. ${ }^{42}$

Von Colson was further developed in Marleasing, where the Court entrenched a doctrine that has become known as "indirect effect" in that 1) although horizontal direct effect may be denied, the individual may take action against a member state that fails to fully and effectively implement a directive and thereby causes the individual to suffer in relation to another private individual or body, and 2) effective implementation requires an interpretation of both subsequent and prior domestic legislation, in line with the objectives and purpose of the directive. ${ }^{43}$ And, recently in Francovich, the Court further suggested that the failure to effectively implement a directive leaves a member state government liable for damages caused thereby. By granting such a private law remedy against a public law body, the Court clearly intended to fully arm the litigant in any action against a member state that fails to implement a directive. ${ }^{44}$

Needless to say, the reception of these principles in the domestic UK courts has been somewhat mixed. Two early cases, Duke and Finnegan, chose to ignore Von Colson by construing the narrow interpretation of a Community directive, and claiming sole competence. ${ }^{45}$ As one commentator has noted, the Von Colson decision was greeted by the UK courts with a mixture of

41. For a commentary on Article 5, see Temple Lang, Community ConstitutionalLaw: Article 5 EEC Treaty, 27 COMMON MKT. L. REV. 645 (1990).

42. Case 14/83, Von Colson v. Land Nordrhem-Westfalen, 1984 E.C.R. 1891.

43. For a commentary on these two particular aspects of Marleasing, see commentary in J. Stuyek \& P. Wyhnek, 28 COMMON MKT. L. REV. 205 (1991).

44. Case 6/90, Francovich v. The Republic, 1992 I.R.L.R. 84. For a thoughtful commentary on Francovich and its implications, see J. Steiner, From Direct Effects to Francovich: Shifting Means of Enforcement of Community Law, 18 EUR. L. REV. 3 (1993).

45. Duke v. Reliance, [1988] 1 App. Cas. 546; Finnegan v. Clowney YTP Ltd., [1990] 2 App. Cas. 407. 
confusion and disbelief. ${ }^{46}$ The restatement and restrengthening of the Court's resolve in Marleasing has certainly clarified the position. In three subsequent cases, Litster, Pickstone and Factortame 1, the UK courts have followed the European Court's directions, even though they have been forced to refrain from applying domestic UK law where required to ensure full effectiveness. ${ }^{47}$

Perhaps the most controversial of these decisions was Factortame, where the European Court held that Article 5 made it incumbent upon domestic judicial systems to grant interim injunctions, temporarily displacing domestic legislation, if the absence of such a remedy in domestic law was the only reason for a failure to "effectively" implement a directive. ${ }^{48}$ The situation may now be clearer, but that has not stopped a number of commentators who have expressed regret over the very obvious confusion that now exists regarding domestic sovereignty and the rule of law. ${ }^{49}$

Two recent decisions have further illustrated the confusion now existing in both the UK courts and amongst academic commentators. In Webb, the House of Lords confessed to being quite unclear as to the extent to which they should interpret existing UK law to be in line with an EC directive. Their reasoning and refusal to implement has been the subject of considerable academic criticism. ${ }^{50}$ In Kirklees, the House of Lords again seemed to be

46. See G. De Burca, Giving Effect to European Community Directives, 55 Mod. L. REV. 215 (1992).

47. Litster v. Forth Dry Dock and Engineering Co. Ltd., [1990] 1 App. Cas. 546; Pickstone v. Freemans Plc., [1989] 1 App. Cas. 67.

48. Case 221/89, [1991] 3 All E.R. 769. For a commentary on the implications of Factortame, see N. Gravells, Disapplying an Act of Parliament Pending a PreliminaryRuling: Constitutional Enormity or Community Law Right?, PUB. L. $582-583$ (1989).

49. Professor Curtin has regretted the "unhappy impasse with regard to the direct enforcement of Community law [which] clearly jeopardizes the fundamental principle of a Community based on the rule of law." See D. Curtin, Directives:The Effectivenessof Judicial Protection of Individual Rights, 27 COMmON MKT L. REV. 709, 711 (1990). See also D. Curtin, The Decentralised Enforcement of Community Law Rights. Judicial Snakes and Ladders, in CONSTTTUTIONAL ADJUDICATION IN EUROPEAN COMMUNITY AND NATIONAL LAW 33, 48 (D. Curtin \& D. O'Keeffe eds., 1992); De Burca, supra note 46, at 223-27. Lewis and Moore have similarly expressed their doubts at the possible effects that the Francovich decision in particular is likely to have in domestic courts. C. Lewis \& S. Moore, Duties, Directivesand Damages in European Community Law, PUB. L. 151 (Spring 1993) (commenting particularly on the inconsistent response in UK courts to the Von Colson-Marleasing-Francovichline of cases).

50. Webb v. EMO Air Cargo (U.K.), Ltd., [1992] 2 All E.R. 43. See Lewis \& Moore, supra note 49, at 156-57. See also N. Gravells, European Community Law in the English Courts, PUB. L. 45 (1993); A. Tanney, 29 Common MKT L. Rev. 1021 (1992). 
quite unclear with regard to the allocation of competences and again failed to fully implement a Community directive. ${ }^{51}$

This confusion with regard to the application of unfamiliar principles-and the next such principle will undoubtedly be subsidiarity-is most extreme in the area of administrative law, remedies and procedures. The increasing disparity and inconsistency between EC administrative law and the administrative law of member states has caused increasing disquiet amongst both academics and judges.

Foremost amongst those demanding a regularisation between EC and member state domestic administrative law has been Professor Juergen Schwarze, who has repeatedly advocated the unification of administrative procedures in their effect on member states and the unification of administrative procedures within member states. Schwarze explicitly suggested that the unification of administrative remedies and procedures would be the most important step towards a new European constitutional order, the responsibility for which should not and could not be left to the European Court alone. ${ }^{52}$

Moreover, a series of recent rulings in the European Court of Justice have suggested that the unification of administrative law is high on the judicial agenda. $^{53}$ One such example is Heylens, a case which very effectively illustrates the existing disparity between $\mathrm{EC}$ and domestic administrative law, and its concurrent effect on the rights of individuals. In Heylens, the European Court held that administrative bodies making decisions which materially affect rights in European law are obliged to make available the reasons for those decisions. Such a "duty" was, the Court said, a fundamental pillar of "effective judicial review." ${ }^{54}$

In UK domestic law, in contrast, there is no common law right to give the reasons for decisions. In a recent case, Exp. Cunningham, the Court of Appeal held that any argument to the contrary was untenable. The decision, however, was more remarkable for the comments of Lord Donaldson, Master of the Rolls, who expressed considerable regret at the apparent disparity between the effect of rights in domestic law and those in EC law. ${ }^{55}$ In a subsequent

51. Kirklees BC v. Wickes Building Supplies Ltd., [1992] 3 W.L.R. 170. See A. Robertson, Effective Remedies in EEC Law before the House of Lords?, 109 LAW Q. REV. 27 (1993).

52. See J. Schwarze, Tendencies Towards a Common Administrative Law in Europe, 16 EUR. L. REV. 3 (1991). SeealsoI. Ward, The Case for a UnifiedAdministrativeLaw Within the European Community, 10 CoMp. L. 101 (1993).

53. See Case 136/79, National Panasonic Case, 1980 E.C.R. 2033; Case 155/79, AM \& S, 1982 E.C.R. 1575; Case 222/86, Heylens, 1987 E.C.R. 4097.

54. Id., Judgment points 14 and 15.

55. R. v. Civil Service Appeals Board, ex. parte Cunningham, [1991] 4 All E.R. 310. For a commentary on Heylens and Cunningham, see I. Ward, Reasons for Decisions - A Way Forward?, 45 ADMin. L. REv. 283 (1993). 
judgment shortly after, Lord Donaldson was even more explicit in his condemnation of the in iquities that had developed in domestic administrative law. ${ }^{56}$

There is, quite clearly, an increasing consensus that the development of European law is now outstripping the capability of domestic legal orders to integrate effectively by a means of ad hoc precedential applications. As is suggested in the final section of this article, what is now demanded is, if not a federal legal order, a more expressly quasi-federated legal order.

The juridical ambition has been tangibly altered during the last decade. The European Court, always a prime dynamic of integration in the Community, has become increasingly more pro-active, and has done so with the clear, if tacit, approval of other Community institutions. The tension that this has created, most recently and most vividly illustrated in Webb and Kirklees in the UK, has now reached the stage where the constitutional order must be revised to accommodate these tensions. This was originally one of the essential ambitions of the Maastricht federalists. The transformation of Maastricht from a constitutional to a purely political document essentially negated this ambition, and resulted in a Treaty which singularly failed to assume these responsibilities. The competency issue, as reflected in the European Court of Justice's approach to the problem of full effectiveness, remains as vexed as ever. It is suggested in the following sections that these problems are likely to worsen as the Court comes to consider the justiciability of subsidiarity and of the Protocols.

\section{ii. Impending Problems: The Justiciability Issue}

Quite apart from the existing tensions in the present European legal order, the Maastricht Treaty establishes a number of potential judicial tensions of its own, primarily through its introduction of subsidiarity and also, to a certain extent, by its liberal use of Protocols. The essentially political nature of subsidiarity has already been stressed. Although it inevitably has a constitutional character, it is first and foremost a political principle. It is also, as has been noted, in the Maastricht Treaty at least, a very ill-defined concept.

56. M. v. Home Office, [1992] 4 All E.R. 139 (commenting that the disparity is anomalous, and, in my judgment, wrong in principle). Such judicial disquiet has been articulated by other senior members of the Bench between the pages of academic journals. See Lord Mackenzie Stuart, Recent Developments in English Administrative Law - the Impact of Europe?, in Du DROIT INTERNATIONAL AU DROIT DE L'INTEGRATION, L.IBER AMORICUM P. PESCATORE 411 (F. Caportori ed., 1987), and also his earlier essay, Legitimate Expectations and Estoppel in Community Law and English AdministrativeLaw, LEGAL ISSUES IN EUROPEAN INTEGRATION 53 (1983), and Lord Slynn, But in England there is no . ., in W. FUERST, 1 FESTSCHRIFT FUER WOLFGANG ZEIDLER 397 (1987). 
A number of academic commentators have already taken note of its potentially confusing effect on existing European law. Moreover, many have also questioned whether, given its obviously political origins, it is justiciable anyway. Nicholas Emiliou recently observed that amongst lawyers, the only "general agreement" is "that there is no agreement on the definition" of subsidiarity. ${ }^{57}$ The most swingeing legal critique to date has come from Professor Toth, who suggests that "the principle of subsidiarity, adopted from the Constitutions of Federal States, is not only not part of pre-Maastricht Community law but that it is totally alien to and contradicts the logic, structure and wording of the founding Treaties and the jurisprudence of the European Court of Justice."\$8 The centrepiece of Professor Toth's critique is the implication in the Treaty that subsidiarity is to be applied only with regard to concurrent jurisdiction. This implication is wholly counter to the existing jurisprudence of the European Court, which has consistently held that the application of subsidiarity in the European legal order can only be with regard to exclusive jurisdiction.

This problem is exacerbated by the precise wording of Article $3 \mathrm{~b}$, which suggests that subsidiarity can only be used to allocate the exercise of already existing competences. This is the direct result of defining the Treaty as establishing a European Union that exists alongside, rather than in place of, the existing Community order. Thus, rather than solving the increasingly damaging problem of competences, Article $3 b$ merely serves to further confuse legally as well as politically.

Professor Toth also echoes the position suggested earlier that despite what the UK government may wish or say, the thrust of subsidiarity is centralising. The fact that the UK demanded the removal of federalism from the Treaty, thus emasculating it as a constitutional document, does not make subsidiarity any less federal; it just makes its exercise a wholly unpredictable event.

Above all, Professor Toth is keen to impress that subsidiarity is a political, and not a legal, principle. So much, he suggests, is clear from the wording and intent of the Treaty. It is not, therefore, intended to be justiciable. The European Court will undoubtedly be approached as to the exercise of the principle, but it is quite possible that it will refuse to exercise any judicial powers to direct its application. If so, subsidiarity will become one of the greatest white elephants in Community history. ${ }^{59}$

57. N. Emiliou, Subsidiarity: An Effective Barrier Against 'the Enterprises of Ambition'?, 17 EUR. L. REV. 383 (1992).

58. A. Toth, The Principle of Subsidiarityin the MaastrichtTreaty, 29 COMMON MKT. L. REV. 1079 (1992).

59. Id. at 1079-1105. 
Even the most supportive commentaries on the subsidiarity principle suggest that whilst it can play a key role in the allocation of competences and the democratisation process of a constitutional order, it can really only do so in a federal order, or one that is at least designed with a comparable degree of coherence. Thus, Deborah Cass has suggested that subsidiarity will be justiciable and the European Court will be willing to exercise its judicial authority in interpreting the principle.

Because the principle is shorn of its familiar federal guise, its resolution by the Court is difficult to predict and may well prove to be quite inconsistent, as it adopts an essentially ad hoc approach to whether principle should be affected so as to centralise or to decentralise, depending on each given case. The Court, as she suggests, may have to exercise its jurisdiction. If it fails to do so, it will be implicitly resigning the ultimate supremacy of European law, a principle which it has developed and placed at the very heart of the European order. ${ }^{60}$ This position is supported by Emiliou who, whilst suggesting that the principle is prima facie probably not justiciable, suspects that the Court will have to, as a matter of policy, assume jurisdiction. Either way, in its present form, subsidiarity "will inevitably destroy the credibility of the Court of Justice which, given its jurisprudence, is arguably the Community's most effective institution. ${ }^{\text {"61 }}$

As was observed earlier in this article, subsidiarity has always been designed by politicians, with the exception of the UK government, to be a centralising and unifying principle. Yet, what subsidiarity does not do is solve any of the vexed problems of competency, which is what it was originally intended to do. Subsidiarity has never played that role, even within a federal system. It is only effective and workable as a political concept, not a legal one. The fact that politicians have chosen to use subsidiarity as a legal constitutional instrument is regrettable. ${ }^{62}$

According to Jacques Delors, one of its strongest advocates, subsidiarity represents a key "way of reconciling what for many appears to be irreconcilable," which is the emergence of Monnet's vision of a United States of Europe, whilst maintaining what he describes as "loyalty to one's homeland." According to Delors, subsidiarity will realise the pluralist vision of sovereignty, as advocated by MacCormick and Koopmans, by determining the delimitation of competences at the same time as enshrining the primacy of European law. ${ }^{63}$

60. See D. Cass, The Word that Saves Maastricht? The Principle of Subsidiarityand the Division of Powers within the European Community, 29 COMMON MKT. L. REV. 1107 (1992).

61. Emiliou, supra note 57, at 403.

62. Id. at 400-05.

63. See Jacques Delors, Address at the Opening Session of the 40th Academic Year of the College d'Europe, Bruges 17 (Oct. 1989). 
A properly established coherent federal order must adopt a principle of plural sovereignty. As Nicholas Emiliou has observed, subsidiarity, being a principle geared purely to delimit competences, is associated with the separation of powers principle, as favoured in European and federal constitutional theory. It is not designed to sit comfortably with theories of unitary sovereignty. The presence of subsidiarity in the Treaty, and its probable justiciability, renders the UK orthodoxy of sovereignty, as articulated by Lord Denning, even less tenable. ${ }^{64}$ How the UK courts will react to subsidiarity is, of course, another uncertain issue. Given the problems experienced in attempting to effect other principles of European law, such as proportionality and legitimate expectations, the answer is anyone's guess. So far, when the House of Lords has encountered the principle as delineated in Article 130R(4), it has adopted a decentralising definition of subsidiarity and reserved the competence of the member state. ${ }^{65}$ If the European Court was to consistently adopt the more centralising approach envisioned by European politicians, then one can only anticipate further confusion in domestic UK courts. This is certainly Professor Hartley's suspicion. ${ }^{66}$

Thus, an immediate threat of action in the European courts regarding the justiciability of the Social Chapter Protocol in both domestic UK and in European law is a very real one. Certainly it has been suggested that the European Court might look unfavourably on the Protocol not least because it so fundamentally undermines the acquis communautaire which was itself enshrined in the Treaty. Indeed, the Protocols, in a rather contradictory fashion, are expressly made to be subject to the acquis communautaire and the existing "provisions" of the Treaty.

It has also been noted that the European Court has a long history of arrogating such a review jurisdiction to itself, even where not foreseen in the Treaties. ${ }^{67}$ It has also been suggested that both the European Court and the UK courts might find the opt-outs, both from the Social Chapter and from the European Monetary Union, to be of questionable legality. Monetary Union, in particular, is explicitly stated in the Treaty to be a centralising measure,

64. Emiliou, supra note 57, at 385-88.

65. See R. v. London Boroughs Transport Committee, ex p. Freight Transport Association Ltd. and others, 1 C.M.L.R. 5 (H.L. 1991) (U.K.).

66. T. Hartley, Constitutional and Institutional Aspects of the Maastricht Agreement, 42 INT'L \& COMP. L. Q. 213, 217-18 (1993).

67. See D. Curtin, The Constitutional Structure of the Union: A Europe of Bits and Pieces, 30 Common MKT. L. Rev. 17, 18-19, 22-23 \& 44-66 (1993). See also, A. Amult, Does the Court of Justice have Inherent Jurisdiction?,27 COMMON MKT. L. REV. 683 (1990) (discussing the Court's arrogation of such powers in the past). 
which can only be effected across the Community ${ }^{68}$ At first glance, it seems unlikely that the UK courts will be prepared to act so obviously as a court of constitutional review and to duly render the Maastricht bill unlawful. However, the real problems will arise if the courts choose to refer the matter to Europe. Given the purely domestic matter of the legislation, they would not immediately need to do so, and may well find it expedient not to do so.

\section{iii. The New "Constitution"}

The original ambition for Maastricht was for it to provide a draft constitution for a new federal European order. In this, it was an unreserved failure. The essential weaknesses of the Treaty, which have been discussed already in this article, include: the abandonment of federalism and the failure to employ a coherent recognisable alternative; the inclusion of a deliberately ill-defined principle of subsidiarity, the judiciability of which remains wholly uncertain; and the widespread use of Protocols, which on a number of occasions opt out of such central tenets of European policy that they represent a very real threat to the acquis communautaire that the Treaty was supposed to enshrine. All of these were political concessions, demanded largely by the UK, at the same time as it campaigned so vigorously both in Westminster and across Europe for its "central role" in Europe. Rarely has any development in the Community's short history been met with such widespread condemnation from so many legal and constitutional commentators.

Professor Toth's relatively restrained, though uncompromising critique, not only criticises the fundamental irrationality of the subsidiarity principle, but also extends it to cover the Treaty as a whole. He suggests:

Rather than being a unitary, precisely drafted instrument, it is an amalgamation of three different types of-fairly poorly drafted-legal texts which fit ill together, over-arched by an introductory part of yet another kind. . . . Above all, it does not allocate competences between the Union and the Member States clearly and systematically-the only context in which the principle of subsidiarity can work. ${ }^{69}$

Professor Deirdre Curtin, on the other hand, is considerably less restrained. In her opinion, "[t]he popular analogy which has been coined, that of the

68. See Emiliou, supra note 57, at 397 . The centrality of a common monetary policy within the Maastricht ambition explains why European leaders refuse to abandon the present EMS, although the width of current money-bands render the spirit of monetary union effectively dead.

69. Toth, supra note 58 , at 1103 . 
construction of a 'temple'. . implies a degree of architectural stability and aesthetic finish which is both inaccurate and pretentious. ${ }^{70}$ There is, she suggests, "more of a 'bricoleur's' amateurism than a master brick-layer's strive for perfection and attention to detail."71 The determination of the European Council to maintain its position as the "inter-governmental organ par excellence" has continued to deny the Community the existence of a true democratic structure and, with it, a true democratic constitution. The power of the Council unavoidably gives the lie to the notion of a single institutional framework so dear to Maastricht ideology. The refusal of the Council to clarify the issue of competences and to redefine or even extend Article 5 prevented any hope of harmonizing the legal order or legal procedures. The Protocols, the justiciability or otherwise of which has already been considered, gave the lie to the ideology itself, and merely served, not to advance the idea of acquis communautaire, but to retard it. ${ }^{72}$

According to Professor Curtin, the Treaty was flawed from its very inception because it proceeded without any clear idea as to where it wanted to go and with no constitutional blueprint which might have served to guide it. It is, in her opinion, a politicians' fudge, the effects of which can only retard the process of European integration, and in the short term plunge the legal order, already straining for a constitutional lead, into still deeper confusion. $^{73}$ One of the more curious facets of the Treaty is its insistence that it represents a Union, in addition to the existing European Community (as it is inexplicably renamed). ${ }^{74}$

The implication is thus to resign any ambitions to represent any new order, least of all a justiciable one. The constitutional order is thus to remain unchanged. So, according to Article F, is the Community's case law. Yet the jurisprudence of the European Court of Justice quite clearly adopts successive Treaties as integral components of the European Community. The Community constitution is, quite simply, the Treaty structure. The ascription of a whole series of non-justiciable constitutional rules is not the least of the Treaty's peculiarities. ${ }^{75}$ Professor Curtin's critique appeared in the 1993 volume of the highly influential Common Market Law Review. The previous issue of the same Review contained a series of similarly critical essays on Maastricht, including those mentioned earlier by Toth and Cass.

That such a mainstream journal should present a series of such articles is itself a point worth noting. The guest editorial position stressed the state

70. Curtin, supra note 67 , at 24.

71. Id.

72. See id. at $24-26,66-69$.

73. Id. at 18-19.

74. It was previously, of course, the European Economic Community.

75. Curtin, supra note 67 , at 20-21. 
of utter confusion in which post-Maastricht Europe now finds itself with regard to constitutional issues. ${ }^{76}$ In conclusion, Professor Curtin suggested:

The result of the Maastricht summit is an umbrella Union threatening to lead to constitutional chaos; the potential victims are the cohesiveness and the unity and the concomitant power of a legal system painstakingly constructed over the course of some 30 odd years. And yet the European Parliament and the national parliaments (and the people in three Member States) are presented with this fait accompli and bullied into believing that only 'bad Europeans' would reject it ... a process of integration, if it has any meaning at all, implies that you can't take one step forward and two steps backward at the same time."

This is a strength of language which should not be ignored. It is suggested, moreover, that it is a language which very effectively reflects the sense of frustration and disillusionment that is currently prevalent amongst European lawyers.

\section{CONCLUSION}

Maastricht represented an opportunity to restructure the legal and constitutional order in Europe. Its failure to do so will continue to reduce the effect of the integrational process. As recent decisions in the UK domestic courts demonstrate, judicial confusion continues, and the full effectiveness of EC law in domestic courts remains uncertain. The political compromises described in the first part of this article effectively negated any possibilities of producing a new constitutional order that could reflect the accelerating pace of social and, indeed, political integration in certain sections of the Community.

Although it was originally intended to describe the new "constitution" of Europe, Maastricht, in the end, became a purely political statement of alarmingly vague intent-an ideal without substance. On the one hand, it proudly granted "citizenship" to the "peoples of Europe;" on the other, it carefully avoided giving them any rights which could be legally enforceable. ${ }^{78}$ Thus,

76. T. Koopmans, Federalism: The Wrong Debate, 29 COMMON MKT L. REV. 1047 (1992).

77. Curtin, supra note 67 , at 67.

78. See C. Closa, The Concept of Citizenship in the Treaty on European Union, 29 COMMON MKT L. REV. 1137 (1992) (stressinghow far the final concept fell short of its initial ambitions, and how legally naked the 'citizen' of Europe stands). 
one of the central "pillars" of the new Europe, the much vaunted citizenship of the Community which is bestowed upon the new European, is no more protected in law-national or international-than citizenship of Iraq, Bosnia or the moon.

Maastricht cannot be termed a constitutional or legal document. Yet by its many sins of omission, the potential effect of the Maastricht Treaty on constitutional and legal matters is considerable. In Professor Toth's opinion, making specific reference to the inclusion of the principle of subsidiarity in the Treaty, "[i]t will weaken the Community and slow down the integration process. It will suit those who would like to see the Community move not towards but away from a truly Federal structure."199 It is submitted that this observation could be applied to the Treaty as a whole. Far from guiding the Community a step further towards a centralised federal order, the Maastricht Treaty could well prove to be the most serious setback so far. It certainly does little to integrate a new European order and does much to disintegrate what already exists.

There is much now at stake. According to Professor Curtin, not least at stake is "[t]he whole future and credibility of the Communities as a cohesive legal unit which confers rights on individuals. ${ }^{180}$ Maastricht's failures render the next "Maastricht," predicted for 1996, to be of even greater importance. If the Community is to be reset on course, it must be done then. Above all, in place of inter-governmental strengthening, the Community must reinforce existing democratic structures. Most importantly, the Community must recognise the need for a more uniform legal order within a clearer, if need be, more overtly, federal constitution. Europe still needs a new constitutional order-after Maastricht, more than ever.

80. Curtin, supra note 67 , at 67. 
